\title{
Pengembangan Ketahanan Pangan Melalui Pemberdayaan Masyarakat di Kawasan Rawan Konflik Timika Papua
}

\section{(Food Security Through Community Empowerment in Conflict Prone Area Timika Papua)}

\author{
Rizal Syarief ${ }^{1}$, Sumardjo $^{2}$, Agit Kriswantriyono ${ }^{3}$, Yulia Puspadewi Wulandari ${ }^{3 \star}$
}

(Diterima Februari 2016/Disetujui Oktober 2017)

\begin{abstract}
ABSTRAK
Penanganan konflik di Papua selama ini lebih sering dilakukan dengan pendekatan represif. Dampaknya tingkat konflik tidak semakin menurun, bahkan penolakan dunia internasional semakin meningkat. Atas dasar itu dibutuhkan pendekatan yang lebih humanistis, diantaranya melalui pemberdayaan. Tujuan penelitian ini adalah mengkaji model pemberdayaan masyarakat di kawasan rawan konflik dalam upaya mewujudkan ketahanan pangan serta strategi replikasi model di wilayah lainnya. Metode penelitian dilakukan dengan action research dan analisis SWOT dalam menyusun strategi replikasi model. Model pemberdayaan dilakukan melalui beberapa cara. Pertama, secara bertahap meningkatkan kemampuan bertani lebih produktif dengan introduksi teknologi pertanian sederhana membawa perubahan perilaku komunitas dari ladang berpindah (nomaden) menjadi bertani menetap (sub sistem). Kedua, bertani dalam rangka menyediakan kebutuhan dasar serta sumber pendapatan harian, mingguan, bulanan, maupun tabungan bagi keluarga. Ketiga, upaya pengembangan usaha melalui kemitraan, dengan pemerintah, perusahaan, dan lembaga keagamaan. Simpul kegiatan pemberdayaan dilakukan melalui Agribisnis Training Center (ATC), sebagai unit yang memfasilitasi semua kegiatan pemberdayaan. Hal yang perlu diperhatikan dalam replikasi model pemberdayaan: identifikasi sasaran program, need assesment, inisiasi kelembagaan, pemilihan teknologi, pendampingan terhadap program, dan kemitraan dengan berbagai stakeholder.
\end{abstract}

Kata kunci: agribisnis, daerah rawan konflik, ketahanan pangan, pemberdayaan masyarakat

\section{ABSTRACT}

Conflict handling in Papua so far is more often done with the repressive approach. The impact of conflict level is not decreasing, even international rejection is increasing. For that reason, a more humanistic approach is needed, including through empowerment. The purpose of this research is to study the community empowerment model in conflict-prone areas as an effort to realize the food security and the strategy of model replication in another area. The research method is done by action research, and SWOT analysis to formulate the strategy of model replication. The empowerment model conducted in several ways. First, gradually improve farming skills more productive-with the introduction of simple agricultural technology brings the change of community behavior from nomadic to the subsystem. Second, farming in order to provide for basic needs and also daily, weekly, monthly income as well as savings for families. Third, business development efforts by partnerships, with the government, companies, and religious institutions. The nodes of empowerment activities are conducted through the Agribusiness Training Center (ATC) that facilitates all empowerment activities. There are several things to consider in the replication model of empowerment: identification of program targets, needs assessment, institutional initiation, technology selection, assistance to the program, and partnerships with various stakeholders.

Keywords: agribusiness, community empowerment, conflict prone area, food security

\section{PENDAHULUAN}

Kabupaten Mimika, Provinsi Papua dikenal sebagai salah satu kawasan rawan konflik. Mereka mampu

1 Departemen IImu Pangan, Fakultas Teknologi Pertanian, Institut Pertanian Bogor, Kampus IPB Darmaga, Bogor 16680.

2 Departemen Sains Komunikasi dan Pengembangan Masyarakat, Fakultas Ekologi Manusia, Institut Pertanian Bogor, Kampus IPB Darmaga, Bogor 16680.

3 Pusat Kajian Resolusi Konflik, Lembaga Penelitian dan Pengabdian Kepada Masyarakat, Institut Pertanian Bogor, Kampus IPB Baranangsiang, Bogor 16154.

* Penulis Korespondensi:

Email: yuliawulandari@apps.ipb.ac.id menghadirkan pembangunan lebih ke hadapan mereka, dirasakan, dan dibutuhkan oleh mereka. Salah satu pendekatan yang bisa menjawab adalah pendekatan pemberdayaan. Melalui pendekatan pemberdayaan masyarakat dilibatkan secara aktif dalam proses pembangunan tersebut, hingga dampak dan pencapaiannya dapat mereka ukur sendiri.

Masyarakat Papua terkenal dengan rasa solidaritas dan kekerabatan yang sangat tinggi. Apapun yang dirasakan sanak saudaranya ikut dirasakan oleh anggota keluarga yang lain termasuk keluarga jauh yang masih dalam satu fam dan suku. Tingginya solidaritas tidak jarang menjadi pemicu konflik hingga berujung terjadinya perang antar suku terlebih jika disertai provokasi pihak-pihak tertentu. Konflik bukan satu-satunya masa- 
lah sosial di Papua, rawan pangan merupakan ancaman lain yang harus dihadapi masyarakat Provinsi Papua. Berdasarkan Peta Ketahanan dan Kerentanan Pangan Indonesia yang di rilis Dewan Ketahanan Pangan, Kementerian Pertanian dan World Food Program (2015) hampir seluruh kota dan kabupaten di Provinsi Papua termasuk ke dalam kategori wilayah rawan pangan prioritas 1 dan 2 . Jika dibandingkan dengan pemetaan pada tahun 2010 tidak ada perubahan status rawan pangan di wilayah ini. Artinya dalam kurun waktu 5 tahun belum ada upaya yang mampu mengubah status rawan pangan di wilayah ini.

Angka kemiskinan Provinsi Papua juga cukup tinggi, data BPS menunjukkan hingga tahun 2014 angka kemiskinan wilayah Provinsi Papua mencapai $27,8 \%$ atau lebih tinggi dari angka kemiskinan Indonesia sebesar 11,25\% (BPS 2015). Kabupaten Mimika sebagai salah satu kabupaten dengan kekayaan sumber daya mineral berlimpah tidak lepas pula dari permasalahan kemiskinan, dengan angka kemiskinan sebesar 16,11\%. Pengentasan kemiskinan dan rawan pangan, menjadi tantangan besar bagi pemerintah.

Pengertian ketahanan pangan tidak lepas dari UU No. 18/2012 tentang pangan. Disebutkan dalam UU tersebut bahwa ketahanan pangan adalah kondisi terpenuhinya pangan bagi negara sampai dengan perseorangan, yang tercermin dari tersedianya pangan yang cukup, baik jumlah maupun mutunya, aman, beragam, bergizi, merata, terjangkau, tidak bertentangan dengan agama keyakinan, budaya masyarakat untuk dapat hidup sehat, aktif, dan produktif secara berkelanjutan. Gangguan terhadap pemenuhan ketahanan pangan berpotensi menimbulkan berbagai gejolak sosial dan politik. Organisasi Pertanian dan Pangan PBB (FAO) mendefinisikan ketahanan pangan sebagai sebuah kondisi di mana semua masyarakat dapat memperoleh pangan yang aman dan bergizi untuk dapat hidup secara sehat dan aktif (Hanafie 2010). Lebih lanjut diuraikan strategi yang dibutuhkan dalam rangka mendukung ketahanan pangan nasional adalah melalui: 1) Pemberdayaan ketahanan pangan masyarakat; 2) Pengembangan sistem dan usaha agribisnis; 3) Mewujudkan kebersamaan antara masyarakat sebagai pelaku dan pemerintah sebagai fasilitator; 4) Menumbuhkan ketahanan pangan pada tingkat rumah tangga; serta 5) Pemantapan koordinasi dan sinkronisasi pihak-pihak terkait perencanaan, kebijakan, pembinaan, dan pengendalian.

Pemberdayaan Masyarakat merupakan salah satu bentuk penyelesaian konflik melalui pendekatan kemandirian (self reliance approach). Konsep pemberdayaan masyarakat sebagai sebuah resolusi konflik ditempuh dengan cara mendorong masyarakat agar mampu meningkatkan kesejahteraannya secara mandiri. Dalam proses ini, lembaga berperan sebagai fasilitator yang mendampingi proses pemberdayaan masyarakat. Konsep pemberdayaan ini juga sejalan dengan konsep ketahanan pangan di mana fokus ketahanan pangan termasuk penyediaan konsumsi pangan di tingkat rumah tangga (Mustofa 2012). Upaya pemberdayaan masyarakat dalam penguatan ketahanan pangan perlu dilakukan dari hulu sampai hilir, diantaranya adalah melalui penguatan onfarm. Penelitian Syarief (2014) terhadap pemberdayaan masyarakat rawan pangan di kawasan perbatasan menunjukkan, bahwa pengembangan pertanian dalam upaya mendukung ketahanan pangan menjadi opsi yang paling tepat, pengalaman yang dimiliki oleh masyarakat di bidang pertanian menjadi modal awal untuk membangun kemandirian.

Kampung Nusantara Bersatu (KNB) dan ATC di Kabupaten Mimika, Provinsi Papua merupakan salah satu model pemberdayaan masyarakat yang diinisiasi oleh Pusat Kajian Resolusi Konflik (CARE) LPPM IPB bekerja sama dengan pemerintah. Model dusun mandiri merupakan model pengelolaan konflik yang digulirkan oleh CARE IPB di arahkan dalam upaya menyiapkan dusun yang memiliki kemampuan untuk menjawab persoalan kebutuhan dasar warga masyarakatnya khususnya kebutuhan pangan, sandang, perumahan, pendidikan, kesehatan, dan sosial budaya dengan memanfaatkan sumber kearifan lokal secara mandiri. Dusun mandiri juga mendorong inisiatif dan partisipasi masyarakat untuk mendorong terciptanya lingkungan yang kondusif, serta mendiseminasikan informasi dan teknologi pertanian di wilayah ini (Gambar 1).

Konsep dasar dusun mandiri pada hakikatnya adalah membangun kesadaran individu untuk mampu memberdayakan dirinya guna meningkatkan kualitas hidup serta berpartisipasi aktif dalam pembangunan dan pengembangan wilayah. Konsep ini sangat sesuai jika di implementasikan sebagai upaya mewujudkan kedaulatan pangan wilayah di mana kemandirian pangan dapat tercapai jika masyarakat di dalamnya ikut berpartisipasi aktif maupun pasif membangun keterjangkauan pangan secara kuantitas dan kualitas mulai dari setiap keluarga. Perbedaannya hanya implementasi ketahanan pangan di wilayah rawan konflik perlu di sertai dengan upaya penyadaran dan pendekatan terhadap komunitas untuk menciptakan suasana yang kondusif dan sikap saling menghargai. Membangun kesadaran politik perlu dilakukan dengan tujuan menumbuhkan sikap nasionalisme dan me-

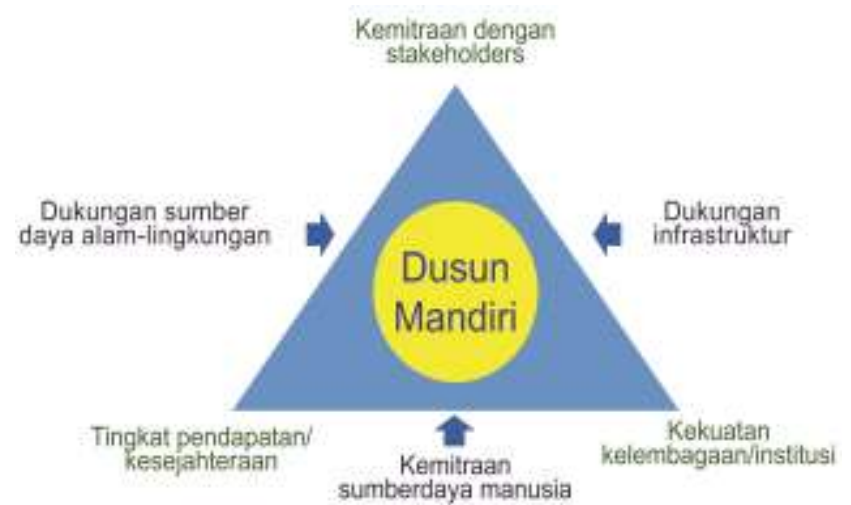

Gambar 1 Elemen-elemen pokok Dusun Mandiri (Sumardjo et al. 2014). 
minimalisasi semangat disintegrasi yang cenderung berkembang di wilayah rawan konflik seperti Papua.

Kegiatan penelitian ini bertujuan mengkaji model pemberdayaan masyarakat di kawasan rawan konflik dalam upaya mewujudkan kedaulatan pangan masyarakat serta fleksibilitasnya untuk diaplikasikan di wilayah lain.

\section{METODE PENELITIAN}

Pelaksanaan penelitian pada tahun pertama dilaksanakan di pemukiman warga Amungme di Satuan Pemukiman (SP) 5 Desa Jilla, Kabupaten Mimika, Provinsi Papua. Pada tahun kedua penelitian dilakukan ATC yang berdomisili di KM 7 arah pelabuhan Pomako Timika. Kegiatan penelitian dilakukan dalam kurun waktu dua tahun, yaitu tahun 2014-2015. Metode penelitian yang dipilih adalah participatory action research. Penelitian dilakukan dengan melibatkan masyarakat untuk bersama-sama menganalisis masalah yang ada dalam kehidupannya, merumuskan rencana kegiatan dan memecahkan masalah. Pada penelitian ini juga dikaji model pemberdayaan masyarakat serta peran ATC dalam mendukung aktivitas pertanian masyarakat. Pengumpulan data primer dilakukan melalui observasi partisipatif, diskusi kelompok yang terfokus (focus group discussion), wawancara mendalam (depth interview) yang berkaitan dengan aspek-aspek yang diperkirakan memengaruhi pola kegiatan ekonomi. Metode analisis yang digunakan dalam penelitian, secara umum mencakup analisis deskriptif kualitatif dengan menggunakan tabulasi atau gambar. Analisis strategi dilakukan dengan metode SWOT.

\section{HASIL DAN PEMBAHASAN}

\section{Faktor Pendukung Program Pengembangan Ketahanan Pangan}

a. Kondisi Sosial, Ekonomi, dan Budaya Masyarakat di Kampung Nusantara Bersatu

Masyarakat di lokasi studi berasal dari suku Amungme, terdiri dari tiga fam (marga utama atau sub etnis), yakni Dekme, Aim, dan Tumomor. Suku Amungme yang telah bermukim KNB berjumlah $40 \mathrm{KK}$ (Kepala Keluarga). Awalnya mereka hidup di pegunungan sehingga menyulitkan mereka untuk memperoleh layanan pendidikan, kesehatan, dan lain-lain. Kegiatan pertanian mereka lakukan dengan sistem berpindah. Setelah hidup menetap di KNB mereka diperkenalkan dengan kegiatan budi daya pertanian dalam rangka penyediaan pangan dan pemenuhan kebutuhan hidup dengan sistem pertanian menetap. Kegiatan pertanian didominasi oleh pertanian lahan kering seperti berkebun palawija atau buah-buahan sesuai dengan kondisi lokal, karena ketiadaan jaringan irigasi.

Warga di KNB memiliki kelembagaan yang sangat sederhana. Dalam hubungan dengan satu kompleks pemukiman, kelompok ini dipimpin oleh seorang kepala suku. Segala hal yang berkaitan dengan proses pem- bangunan dan pengaturan bagi komunitas tersebut diputuskan oleh kepala suku. Lahan di sekitar pemukiman adalah lahan adat yang saat ini dipegang oleh salah seorang tokoh petani yang sebagian sudah tergarap secara semi intensif. Konsepsi lahan adat dalam kasus ini mengandung konotasi bahwa lahan yang dipegang oleh seseorang dan harus dikelola untuk kepentingan kelompok, bukan untuk memperkaya diri sendiri. Lahan tersebut dapat diolah dan dimanfaatkan secara bersama dengan cara-cara yang disepakati bagi kepentingan warga anggotanya.

Kegiatan pembukaan dan persiapan lahan dilakukan oleh kaum laki-laki, selanjutnya mayoritas aktivitas pertanian lebih banyak melibatkan kaum wanita mulai dari penanaman, pemeliharaan, hingga panen. Pada awalnya hasil panen dijual ke pasar, terutama untuk hasil tanaman umbi-umbian, sayuran, dan pisang sesuai dengan kemampuan membawanya atau sesuai dengan nilai kebutuhan yang diperlukan setiap mereka ke pasar. Pengenalan kegiatan budi daya pertanian secara perlahan mengubah pola hidup mereka dari sekedar berburu dan mengumpulkan makanan menjadi produsen produk pertanian.

\section{b. Kondisi Sumber Daya Alam di Lokasi Studi}

Kondisi wilayah Kabupaten Mimika yang didominasi lahan kering, menjadikan usaha tani lahan kering sebagai potensi pertanian yang paling sesuai untuk dikembangkan di wilayah tersebut. Meski demikian ratarata usaha pertanian berkembang secara sederhana, sub sisten atau sebatas memenuhi kebutuhan pangan rumah tangga. Komoditas ubi dan betatas (keladi) yang paling banyak dibudidayakan di wilayah ini. Usaha pertanian lahan kering dilakukan masyarakat dengan cara membuka lahan kawasan hutan yang berada di sekitar pemukiman masyarakat. Kegiatan pertanian juga dilakukan di sekitar rumah warga dengan penanaman pisang, singkong, ubi jalar, pepaya, dan pinang. Kelima jenis tanaman tersebut merupakan tanaman yang banyak dikembangkan masyarakat di wilayah studi. Kehadiran CARE IPB telah memperkenalkan beberapa komoditas baru dalam kegiatan pertanian mereka, termasuk beberapa tanaman keras (jambu kristal, pepaya calina, dan lain-lain).

Kegiatan budi daya ternak maupun perikanan sangat minim karena mayoritas ternak dan ikan selama ini diperoleh dengan cara berburu di kawasan hutan dan sungai sekitar pemukiman warga. Ketersediaan sumber daya perikanan yang masih berlimpah menjadi salah satu alasan usaha budi daya perikanan kurang diminati.

\section{Model Pemberdayaan Masyarakat Mewujudkan Ketahanan Pangan}

Secara umum kemampuan masyarakat untuk memenuhi kebutuhan pangan sudah relatif memadai meski masih berskala untuk pemenuhan pangan keluarga. Ketergantungan terhadap konsumsi beras yang masih cukup tinggi dikala sumber karbohidrat lain relatif tersedia juga menjadi salah satu permasalahan. Tingginya harga bahan pangan menyebabkan upaya mewujudkan pola pangan seimbang belum dapat terpenuhi. Budaya pangan juga turut memengaruhi kecukupan asupan gizi 
di dalam keluarga. Hasil studi menunjukkan kondisi eksisting dari $40 \mathrm{KK}$ di KNB, bahwa mayoritas masyarakat KNB di wilayah studi memenuhi kebutuhan pangan dari hasil kebun. Pola pangan yang terbentuk masih mayoritas didominasi oleh sumber karbohidrat dan protein nabati seperti umbi-umbian, sayur, dan buah. Konsumsi protein hewani umumnya hanya pada perayaan-perayaan tertentu dan diperoleh melalui kegiatan berburu. Masih ada faktor pembatas dalam pengembangan pertanian berupa ketersediaan lahan terbatas, ketersediaan sarana produksi pertanian, serta belum adanya sentuhan teknologi budi daya pertanian yang memadai.

Program pengembangan pertanian dilakukan dalam upaya mewujudkan kedaulatan pangan pada komunitas KNB. Langkah awal yang dilakukan tim CARE LPPM IPB selaku pendamping pada kegiatan ini adalah dengan melakukan need assesment. Need assessment dilakukan dalam upaya menemu kenali permasalahan, kekuatan, maupun peluang pengembangan ketahanan pangan di wilayah studi. Need assesment dilakukan melalui pemetaan kebutuhan masyarakat yang dilakukan oleh masyarakat sendiri serta melalui analisis SWOT (Tabel 1).

\section{a. Pertanian Terpadu}

Fokus perhatian dalam pengembangan sistem pertanian terpadu ini adalah meningkatkan kemampuan penguasaan iptek bagi masyarakat KNB, pembelajaran pertanian yang terorganisir dan pengaturan pengelolaan pascapanen serta keseluruhannya akan bermuara pada pelestarian lingkungan, peningkatan pendapatan petani, serta integrasi sosial antar orang Amungme. Tahapan implementasi antara lain:

- Optimalisasi pemanfaatan lahan

Ada tiga jenis lahan yang digunakan dalam aktivitas pertanian terpadu. Pertama, lahan adat yang penguasaannya di bawah tokoh masyarakat setempat, dengan luas lebih dari 3 ha. Lahan ini didesain sebagai lahan pembelajaran sekaligus berfungsi sebagai lahan produksi bagi kelompok dan anggotanya, sedangkan, tamatan dari kerja bersama di lahan adat akan memperoleh pengetahuan untuk mengembangkannya secara mandiri di kebunnya sendiri. Kedua, lahan yang diakui sebagai lahan masing-masing keluarga. Ketiga, lahan pekarangan. Dalam hal ini konsep yang dikedepankan adalah tanaman rempahrempah dan pohon penyejuk yang sekaligus berfungsi untuk konsumsi sehari-hari (Gambar 2).

- Organisasi kerja

Kerja orang Amungme di bidang pertanian adalah kerja keluarga. Karena itu, dalam proses melibatkan atau memberdayakan mereka haruslah mendefinisikan secara tegas hak-hak individu atau keluarga dalam pekerjaan yang dijalaninya. Pendekatan kelompok tetap menjadi perhatian dan dikombinasikan dengan penegasan hak-hak individu dalam kelompok dan pemisahan usaha kelompok dari usaha keluarga atau perorangan. Dalam sistem pertanian Suku Amungme pihak yang paling banyak menangani pemasaran hasil dan berbelanja di pasar adalah perempuan. Karena itu, perempuan akan diberi peran khusus dalam sistem pertanian terpadu, baik pada tahap kegiatan produksi maupun pemasaran hasil.

Tabel 1 Analisis strategi pengembangan pertanian di wilayah studi

\begin{tabular}{|c|c|c|}
\hline Internal & $\begin{array}{l}\text { Strenght (Kekuatan): } \\
\text { - Mayoritas mata pencaharian masya- } \\
\text { rakat di wilayah studi di bidang pertanian } \\
\text { - Adanya budaya melibatkan seluruh } \\
\text { anggota keluarga dalam aktivitas per- } \\
\text { tanian } \\
\text { - Adanya keinginan untuk mengembang- } \\
\text { kan usaha pertanian (termasuk peterna- } \\
\text { kan \& perikanan) } \\
\text { - } \text { lkatan kekerabatan yang tinggi dalam } \\
\text { komunitas KNB }\end{array}$ & $\begin{array}{l}\text { Weakness (Kelemahan): } \\
\text { - } \quad \text { Adanya potensi konflik akibat perebutan } \\
\text { posisi ketua kelompok tani } \\
\text { - Kegiatan budi daya yang dilakukan } \\
\text { minim teknologi } \\
\text { - Belum ada upaya pengolahan produk } \\
\text { pertanian menjadi produk sekunder } \\
\text { - Kebutuhan menjual produk pertanian } \\
\text { lebih dilatarbelakangi jika ada kebutu- } \\
\text { han mendesak, selebihnya lebih disukai } \\
\text { di simpan sebagai cadangan bahan } \\
\text { pangan keluarga }\end{array}$ \\
\hline $\begin{array}{l}\text { Opportunity (Peluang): } \\
\text { - Adanya permintaan pasar } \\
\text { terhadap produk perta- } \\
\text { nian, peternakan, dan } \\
\text { perikanan } \\
\text { - Dukungan pemerintah } \\
\text { daerah, TNI, perusahaan, } \\
\text { gereja, dan perguruan } \\
\text { tinggi }\end{array}$ & $\begin{array}{l}\text { Strategi S-O } \\
\text { - Pengembangan pertanian berbasis } \\
\text { agribisnis } \\
\text { - Optimalisasi pemanfaatan lahan melalui } \\
\text { pertanian terintegrasi } \\
\text { - Penguatan kelembagaan petani dalam } \\
\text { upaya pengembangan kemitraan }\end{array}$ & $\begin{array}{l}\text { Strategi W-O } \\
\text { - Penentuan ketua kelompok tani yang } \\
\text { didukung seluruh anggota } \\
\text { - Adanya pembagian tugas dan tanggung } \\
\text { jawab yang jelas dalam kelompok } \\
\text { - Peningkatan kapasitas masyarakat me- } \\
\text { lalui pelatihan budi daya maupun } \\
\text { pengolahan hasil } \\
\text { - Pengembangan pasar produk pertanian }\end{array}$ \\
\hline $\begin{array}{l}\text { Threats (Ancaman): } \\
\text { - Persaingan produk se- } \\
\text { jenis } \\
\text { - Harga jual produk }\end{array}$ & $\begin{array}{l}\text { Strategi S-T } \\
\text { - Pelatihan penanganan pascapanen } \\
\text { - Pengembangan pasar produk pertanian }\end{array}$ & $\begin{array}{l}\text { Strategi W-T } \\
\text { - Penguatan peran kelompok dalam } \\
\text { pemasaran produk pertanian } \\
\text { - Peningkatan daya tawar produk melalui } \\
\text { produk olahan }\end{array}$ \\
\hline
\end{tabular}




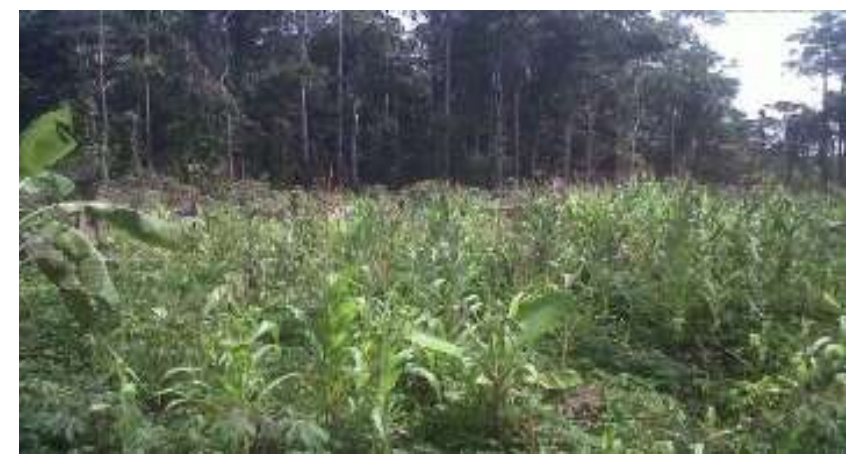

Gambar 2 Pemanfaatan lahan keluarga untuk budi daya jagung.

\section{- Penentuan komoditas}

Pemilihan komoditas dilakukan berdasarkan pertimbangan seperti, kemudahan untuk dibudidayakan, kesesuaian budi daya dengan lingkungan biofisik, memiliki nilai ekonomi di pasaran, dan dapat menjadi sumber pakan alternatif bagi ternak yang dibudidayakan, sedangkan ada lima komoditas yang diusahakan dalam sistem usaha tani terpadu yaitu, tanaman (umbi-umbian dan sayuran), ternak (ayam dan babi), dan perikanan (lele) (Gambar 3).

- Penguatan kapasitas masyarakat

Diseminasi informasi mengenai inovasi-inovasi di bidang pertanian ini dilakukan melalui kegiatan pelatihan kepada masyarakat sasaran. Pelatihan dilakukan dengan metode demonstrasi dan praktik langsung dalam kegiatan budi daya. Pelatihan juga diikuti oleh satgas TNI yang akan menjadi pendamping masyarakat sehari-hari. Pelatihan dilakukan oleh tim IPB meliputi pelatihan budi daya pertanian, peternakan, dan perikanan (Gambar 4).

\section{b. Inisiasi Agribisnis Training Center (ATC)}

Pada tahun kedua penelitian di arahkan pada keberadaan ATC yang berdomisili di KM 7 arah pelabuhan Pomako Timika dan berada di belakang Balai Karantina Benih, Dinas Pertanian, Kabupaten Mimika. Inisiasi pembangunan ATC telah diawali sejak awal 2014 (pemilihan dan pengurusan lahan) ini dilakukan dengan bekerjasama dengan berbagai pihak diantaranya dengan warga binaan Kampung Mandiri Nusantara, komunitas adat, dan pemerintah daerah Kabupaten Mimika. Pembangunan ATC pada awalnya di tujukan sebagai sarana untuk melatih kaum wanita masyarakat binaan sebagai target utama dan masyarakat umum.

Training center seluas kurang lebih $12.000 \mathrm{~m}^{2}$ ini di dalamnya difasilitasi oleh honai pertemuan (gazebo), kolam ikan, green house, rumah olah kompos, kebun bibit, dan lahan pertanian. ATC telah dilengkapi kandang babi kapasitas 100 ekor, kandang sapi kapasitas 5 ekor, kandang ayam kampung kapasitas 20 ekor, rumah pembibitan 2 unit, menara air, dan instalasi biogas.

Pada tahap awal telah diupayakan ditanam di kebun sebagai bagian dari uji kecocokan ekologis, diantaranya, tomat, cabai, timun, kangkung darat, bayam, sawi, kacang panjang, dan melon. Pertana-

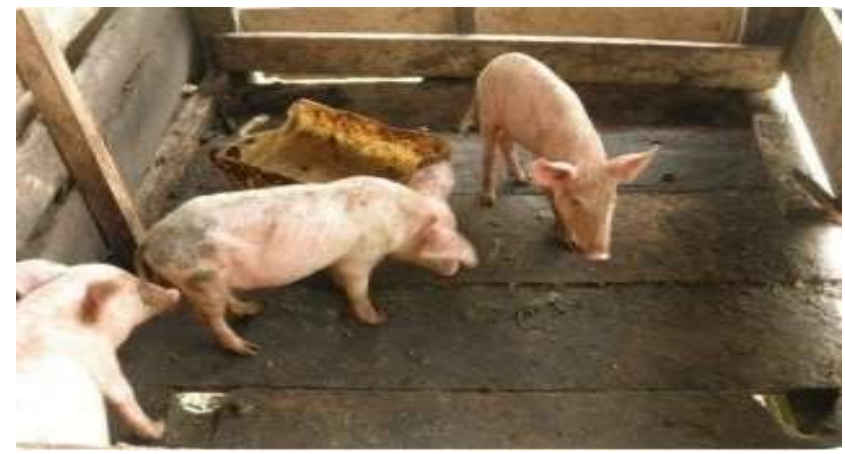

Gambar 3 Budi daya babi.

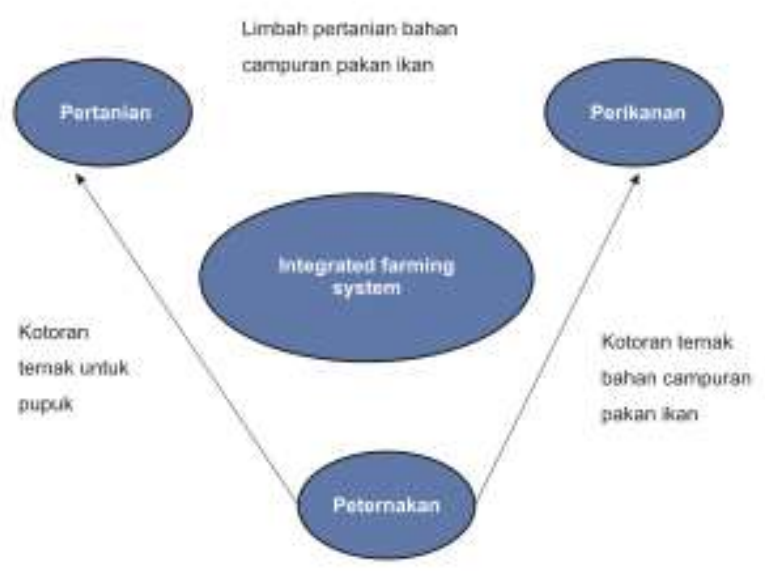

Gambar 4 Konsep pertanian terpadu di wilayah studi.

man sayuran yang dikembangkan di kebun diklat ini menggunakan sistem persis seperti yang diajarkan ketika dilaksanakan kunjungan ke kebun PT EWS di Purwakarta. Beberapa teknologi yang diadopsi diantaranya adalah sistem mulsa dan cebongan (menggunakan pemanas untuk melubangi mulsa). Diharapkan dengan menerapkan sistem ini hasil yang dicapai akan lebih baik.

Kegiatan budi daya yang dilakukan di dalam ATC oleh masyarakat binaan KBN dan hasilnya di manfaatkan langsung oleh mereka baik untuk dikonsumsi atau dijual. Adapun peran ATC sebagai sumber inovasi pengetahuan di bidang pertanian diupayakan tetap berjalan melalui kemitraan dengan lembaga penelitian di bawah dinas terkait maupun perguruan tinggi lokal. Keberadaan training center di KM 7 Timika yang sebelumnya lebih banyak fokus untuk mendukung kegiatan pemberdayaan terhadap warga binaan di KBN, eksistensinya dioptimalkan dan dikembangkan untuk melayani warga Kabupaten Mimika dan sekitarnya (Gambar 5).

\section{c. Peran Para Pihak}

Dalam konteks pemberdayaan petani agribisnis peran kemitraan memiliki peranan penting dalam upaya memberikan keberdayaan atau kekuatan kepada petani untuk dapat mengakses berbagai sumber daya yang diperlukan oleh usaha agribisnis (Erfit 2011). Berdasarkan hasil pemetaan sosial serta implementasi kegiatan di lapang, upaya pengemba- 

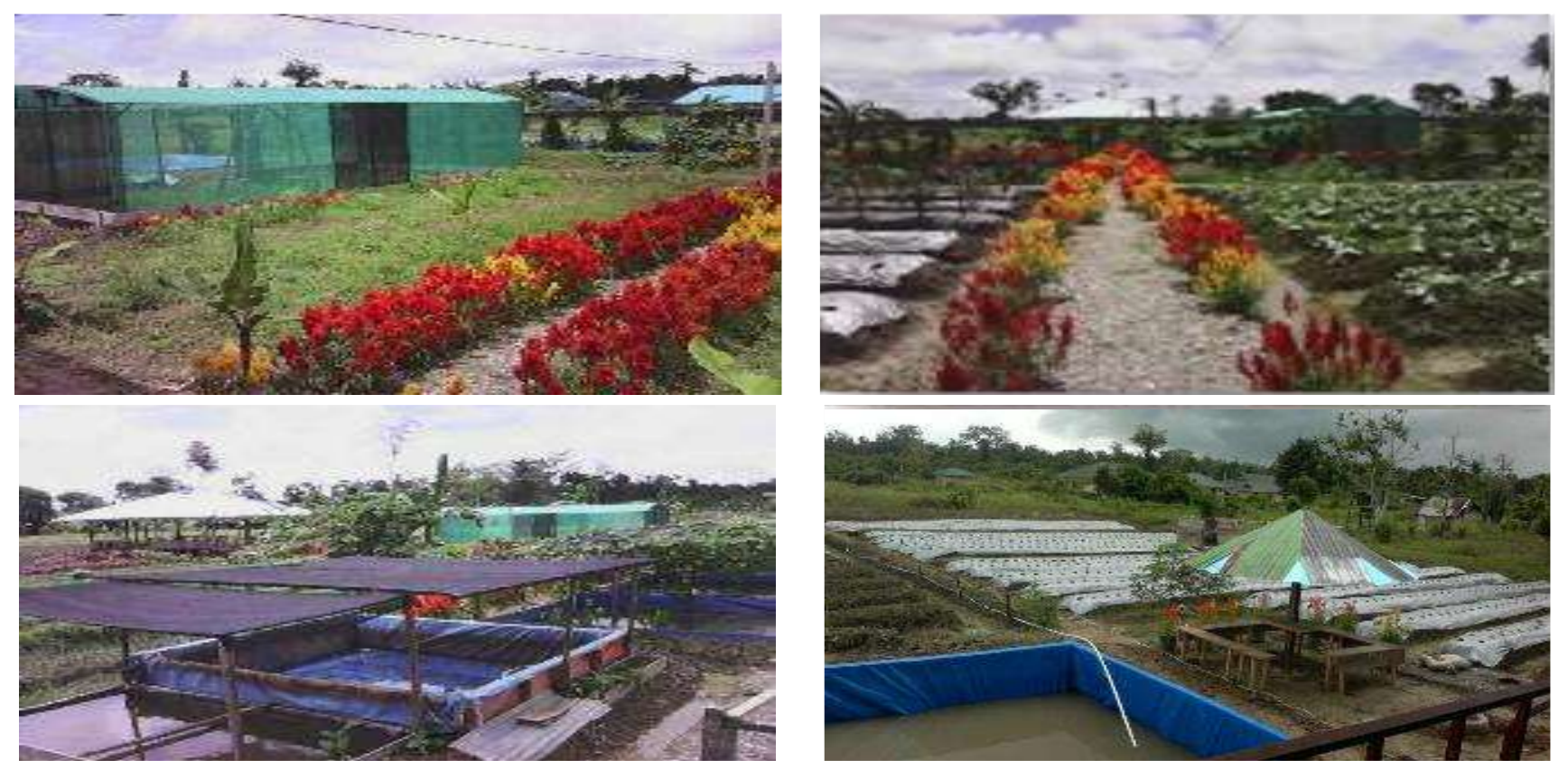

Gambar 5 Agribisnis Training Center di Timika Tahun 2014.

ngan sistem pertanian terpadu di wilayah studi setidaknya mendapat dukungan dari banyak pihak mulai dari pemerintah, gereja, perusahaan, dan LSM lokal (Gambar 6).

\section{- Peran gereja}

Gereja merupakan salah satu institusi yang paling dikenal luas oleh masyarakat di Timika. Berbagai kesulitan yang dihadapi oleh jemaat gereja di sektor perekonomian mendorong pihak gereja untuk berkiprah di bidang ekonomi bagi jemaatnya. Dalam hal ini peran gereja diantaranya adalah dalam mengorganisir dan mendorong jemaat terlibat dalam kegiatan usaha pertanian terpadu.

- Peran perusahaan

Pihak lain yang erat kaitannya dengan pengembangan pertanian terpadu di wilayah studi adalah keberadaan PT Freeport Indonesia. Peran perusahaan dalam pemberdayaan ekonomi masyarakat melalui program CSR bagian yang disebut dengan Social Local Development. Dalam kaitannya dengan pengembangan usaha agribisnis masyarakat KNB dan peran perusahaan dalam hal ini adalah sebagai pasar produk dalam rangka pemenuhan kebutuhan pangan karyawannya. Secara rutin petani melalui koperasi perusahaan menyuplai kebutuhan pangan setiap minggu.

\section{- Peran pemerintah}

Peran utama pemerintah dalam hal ini sangat besar mulai dari awal proses relokasi dan pembinaan warga KNB. Pembinaan secara khusus terkait program pengembangan pertanian mendapat dukungan pemerintah daerah melalui dinas pertanian berupa bantuan bibit pinang, dukungan dari satgas TNI berupa peminjaman lahan untuk budi daya ternak babi, serta pendampingan secara kontinu dalam kegiatan budi daya pertanian, peternakan, dan perikanan.

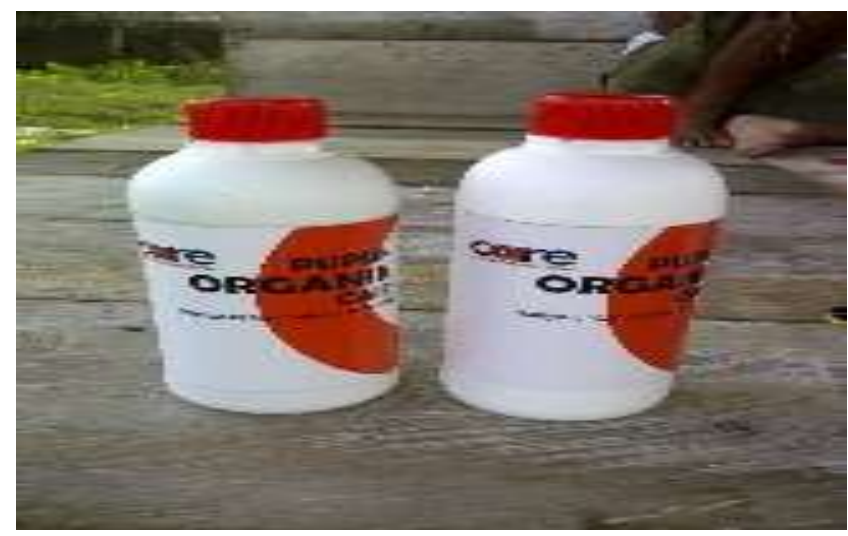

Gambar 6 Pupuk organik cair sebagai salah satu hasil pelatihan di ATC.

Lahan pekarangan dapat dioptimalkan pemanfaatannya untuk memproduksi pangan dan papan di satu sisi, sekaligus memelihara dan memperbaiki kondisi ekologis serta meningkatkan dan mempertahankaan biodiversitas (Rauf et al. 2013). Keuntungan/kebaikan yang diperoleh dalam penerapan sistem pertanian terpadu (termasuk sistem agroforestry) adalah terjadinya peningkatan keluaran hasil (output) yang lebih bervariasi, yaitu berupa pangan, pakan, serat, kayu, bahan bakar, pupuk hijau, dan kandang. Selain itu secara ekonomi sistem pertanian terpadu memiliki keuntungan lainnya, yaitu memperkecil resiko kegagalan panen.

\section{Model Pertanian Terpadu dan Penguatan Ketahanan Pangan Keluarga}

Salah satu konsep yang dikembangkan oleh usaha pertanian terpadu di Kabupaten Mimika adalah bagaimana mengarahkan petani untuk dapat memiliki penghasilan harian, mingguan, bulanan, dan musiman. Hal ini dilakukan melalui pengaturan pola tanam, 
pemilihan komoditas, dan siklus panen. Pengaturan tersebut dilakukan bukan hanya untuk meningkatkan pendapatan petani tetapi juga menciptakan ketersediaan produk pangan secara kontinu. Hasil penelitian Rusyantia (2010) menunjukkan, bahwa variabel yang berpeluang memengaruhi ketahanan pangan rumah tangga diantaranya adalah besar rumah tangga, pendapatan rumah tangga, pengeluaran pangan rumah tangga, dan ketersediaan pangan pokok dari produksi sendiri. Untuk itu, di dalam kawasan ATC di bangun model budi daya beberapa jenis tanaman. Untuk menciptakan penghasilan harian dilakukan melalui produksi sayuran, untuk penghasilan mingguan melalui produksi umbi-umbian seperti talas, penghasilan bulanan dengan produksi pinang, dan penghasilan musiman melalui budi daya buah-buahan (Tabel 2) dan (Gambar 7).

ATC membuka peluang bagi masyarakat untuk berkonsultasi terkait pemilihan jenis komoditas atau produk usaha tani sesuai dengan kebutuhan pasar. Adapun penentuan jenis komoditas yang dibudidayakan sepenuhnya menjadi otoritas petani. Dengan demikian telah terjadi perubahan pola perilaku petani dari awalnya nomaden menjadi sub sistem dan kini mulai berorientasi agribisnis dengan mempertimbangkan aspek pasar.

Adanya ketersediaan produk usaha tani warga masyarakat yang dapat memenuhi kebutuhan harian, mingguan, bulanan, dan musiman ternyata telah membuat petani bertahan mengelola usaha taninya secara berkelanjutan. Hal ini diperkuat dengan tersedianya kebutuhan masyarakat yang ternyata dapat menjadi peluang pasar usaha tani warga masyarakat.

Tabel 2 Produk usaha tani dan pemanfaatan produk

\begin{tabular}{lcccc}
\hline \multirow{2}{*}{ Produk } & \multicolumn{5}{c}{ Memenuhi kebutuhan } \\
\cline { 2 - 5 } Telur & 1 & 2 & 3 & 4 \\
Ayam & $\sqrt{ }$ & $\sqrt{ }$ & & $\sqrt{ }$ \\
Babi & $\sqrt{ }$ & $\sqrt{ }$ & & \\
Sayuran & & & $\sqrt{ }$ & \\
Umbi-umbian & $\sqrt{ }$ & & $\sqrt{ }$ & \\
Buah-buahan & $\sqrt{ }$ & $\sqrt{ }$ & & $\sqrt{ }$ \\
Ikan & $\sqrt{ }$ & & & \\
Pinang & $\sqrt{ }$ & & & \\
\hline Keterangan: 1) sendiri; 2) & pasar lokal; 3) mitra; dan 4) \\
budaya/adat. &
\end{tabular}
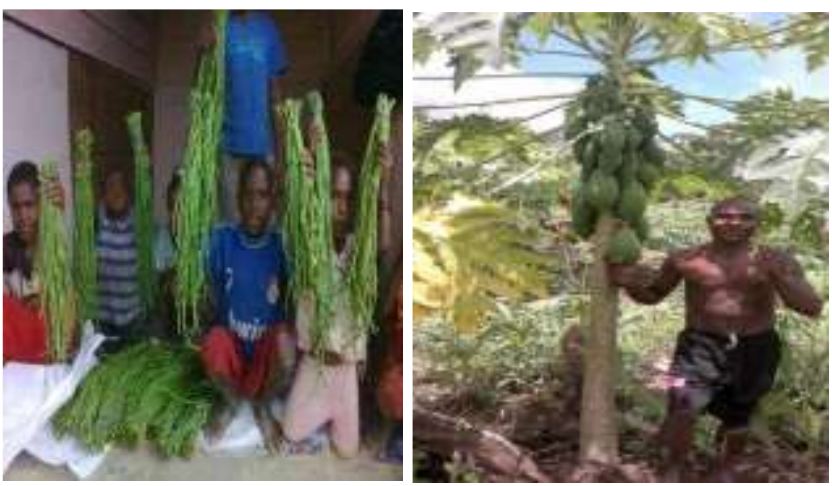

Gambar 7 Hasil panen petani.
Produk-produk usaha tani khususnya ternak selain untuk memenuhi kebutuhan tani juga berkaitan dengan kebutuhan ritual adat warga setempat sehingga pilihan ternak yang dimaksud adalah ternak babi (Tabel 3).

Kegiatan warga di Kampung Mandiri sudah semakin menggeliat setelah mereka mendapatkan Delivery Order (DO) langsung dari mitra lokal perusahaan besar untuk memenuhi kebutuhan karyawannya. Proses penjualan dilakukan melalui Koperasi Usaha Bersama Amungsa Amungne-gelemjaya. DO ini didapatkan setelah mereka dapat menunjukkan potensi panen beberapa komoditas sayuran yang diproduksi di kebun mereka. Sebanyak 27 komoditas yang dapat di salurkan kepada koperasi tersebut.

Kemampuan warga dalam hal penanganan pascapanen semakin baik dengan adanya DO tersebut. Semua komoditas harus dalam keadaan segar dan layak dikonsumsi, serta dalam ikatan yang rapi. Berbeda dengan jika mereka menjual di pasar tradisional, di mana dari kebun langsung mereka bawa tanpa ada penanganan terlebih dahulu, dengan demikian, secara tidak langsung pendidikan aspek kebersihan sudah mulai ditanamkan kepada warga melalui kegiatan pertanian (Gambar 8).

Pada tahap berikutnya, upaya penguatan kedaulatan pangan di tempuh melalui pengembangan komoditas organik. Hal ini dilakukan dengan mendorong pemanfaatan kotoran ternak sebagai pupuk organik serta pengenalan aneka pestisida organik dalam pengendalian hama dan penyakit.

Potensi pengembangan produk pertanian organik terbuka lebar mengingat pasar utama produk-produk

Tabel 3 Produk usaha tani dan pemanfaatan produk

\begin{tabular}{lllll}
\hline \multirow{2}{*}{ Produk } & \multicolumn{5}{c}{ Memenuhi kebutuhan } \\
\cline { 2 - 5 } Telur & 1 & 2 & 3 & 4 \\
Ayam & $\sqrt{ }$ & $\sqrt{ }$ & & \\
Babi & $\sqrt{ }$ & $\sqrt{ }$ & & $\sqrt{ }$ \\
Sayuran & & & & \\
Buah-buahan & $\sqrt{ }$ & & $\sqrt{ }$ & \\
Umbi-umbian & $\sqrt{ }$ & $\sqrt{ }$ & $\sqrt{ }$ & \\
Ikan & $\sqrt{ }$ & & & \\
Pinang & $\sqrt{ }$ & & & $\sqrt{ }$ \\
\hline
\end{tabular}

Keterangan: 1) sendiri; 2) pasar lokal; 3) mitra; dan 4) budaya/adat.

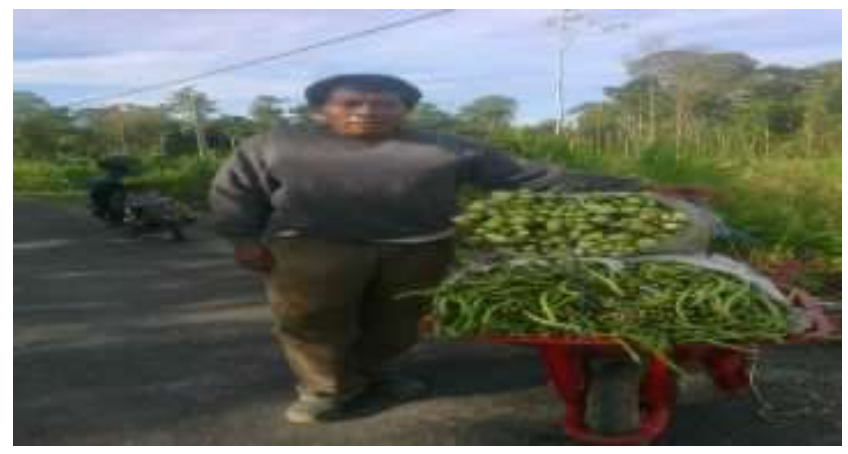

Gambar 8 Penangangan pascapanen diikat dan dikemas dalam karung. 
pertanian adalah untuk menyuplai kebutuhan konsumsi karyawan perusahaan. Meski petani binaan belum sepenuhnya memahami manfaat dari produk organik tetapi dengan pengenalan-pengenalan yang dilakukan ke depan kesadaran terhadap penggunaan produk organik semakin meningkat terlebih jika dikaitkan dengan peningkatan efisiensi usaha pertanian.

Program pertanian terpadu yang dikembangkan telah mendorong pada upaya penguatan kedaulatan pangan dengan menciptakan kemampuan petani binaan untuk menjaga penyediaan pangan keluarga sepanjang tahun sekaligus memiliki kemampuan memilih produk yang memiliki nilai ekonomi tinggi. Kedaulatan pangan juga dapat dilihat dari diversifikasi pangan dalam upaya mendukung ketahanan pangan nasional dipenuhi dengan mendorong pengembangan pangan pokok lokal berupa umbi-umbian.

\section{Strategi Replikasi Model Penguatan Ketahanan Pangan}

Adanya program pendampingan agribisnis mampu memberikan kontribusi peningkatan pendapatan kepada anggota kelompok. Mempertimbangkan dampak positif yang ditimbulkan, dan program ini cukup potensial untuk dikembangkan di wilayah lain. Dalam upaya pengembangan ketahanan pangan melalui kegiatan agribisnis langkah-langkah yang perlu mendapat perhatian, yaitu 1) Identifikasi sasaran program; 2) Need Assesment, bertujuan melihat potensi, permasalahan, kebutuhan, maupun tantangan dalam pengembangan program; 3) Inisiasi kelembagaan seperti kelompok tani atau ternak, berfungsi untuk meningkatkan daya tawar petani serta memudahkan koordinasi kegiatan; 4) Pemilihan produk terkait pasar dan peluang memenuhi kebutuhan harian, bulanan, dan tabungan; 5) Pendampingan terhadap program; dan 6) Membuka peluang kemitraan dengan berbagai stakeholder.

Outcome kegiatan ini antara lain meningkatnya inisiatif dan kemandirian warga untuk mempertahankan keberlangsungan siklus bertani dengan teknologiteknologi yang diperkenalkan serta upaya mendorong terciptanya ketahanan dan kemandirian pangan yang mengarah pada pencapaian kedaulatan pangan. Kegiatan agribisnis yang dilakukan kecara berkelompok menjadi sebuah pendekatan terhadap komunitas untuk menciptakan suasana yang kondusif dan sikap saling menghargai.

\section{KESIMPULAN}

Kampung Nusantara Bersatu (KNB) dan Agribisnis Training Center (ATC) di Kabupaten Mimika, Provinsi Papua merupakan salah satu model dusun mandiri yang di arahkan dalam upaya menyiapkan dusun yang memiliki kemampuan untuk menjawab persoalan kebutuhan dasar warga masyarakatnya, diantaranya kebutuhan pangan. Upaya mewujudkan ketahanan pangan melalui pemberdayaan masyarakat di kawasan rawan konflik diantaranya ditempuh melalui optimalisasi sumber daya lokal, adopsi teknologi tepat guna, penguatan kelembagaan, penguatan kapasitas SDM, dan kemitraan. Kegiatan pemberdayaan masyarakat yang dilakukan membawa dampak positif. Pertama, introduksi teknologi pertanian sederhana membawa perubahan perilaku komunitas dari nomaden menjadi sub sistem. Kedua, masyarakat memiliki sumber pendapatan harian, mingguan, bulanan, musiman, tahunan, maupun tabungan bagi keluarga. Ketiga, upaya pengembangan usaha dengan memanfaatkan kemitraan, baik dengan pemerintah, perusahaan, dan lembaga keagamaan. Simpul kegiatan pemberdayaan dilakukan melalui ATC, sebagai unit yang memfasilitasi semua kegiatan pemberdayaan di wilayah konflik di Timika khususnya dan Papua pada umumnya. ATC juga sebagai sumber inovasi pengetahuan dan konsultasi terkait aspek pertanian berwawasan teknologi, serta pascapanen dan pasar. Ada beberapa hal yang perlu diperhatikan dalam replikasi model pemberdayaan antara lain, identifikasi sasaran program, need assesment, inisiasi kelembagaan, pemilihan produk, pendampingan terhadap program, dan kemitraan dengan berbagai stakeholder.

\section{UCAPAN TERIMA KASIH}

Penulis mengucapkan terima kasih kepada Direktorat Pendidikan Tinggi, Kementerian Pendidikan dan Kebudayaan atas dukungan yang diberikan dalam pelaksanaan penelitian. Penulis juga mengucapkan terima kasih kepada Masyarakat SP 5 Desa Jilla, Distrik Diloane, Kabupaten Mimika, Provinsi Papua atas kerjasamanya dalam penelitian ini.

\section{DAFTAR PUSTAKA}

[BPS] Badan Pusat Statistik. 2015. Perhitungan dan Analisis Kemiskinan Makro Indonesia 2014. Jakarta (ID): Badan Pusat Statistik.

Djaenudin M. 2011. Riset LIPI: Empat Akar Masalah Konflik Papua. [Internet]. (Diunduh 19 April 2014). Tersedia pada http://nasional.vivanews.com/news/ read/264390-riset-lipi-empat-akar-masalah-papua.

Dewan Ketahanan Pangan, Kementerian Pertanian dan World Food Program. 2015. Peta Ketahanan dan Kerentanan Pangan Indonesia 2015. Jakarta (ID): Dewan Ketahanan Pangan, Kementerian Pertanian dan World Food Program.

Erfit. 2011. Pemberdayaan Petani Dengan Kemitraan pada Agribisnis Hortikultura. Jurnal Penelitian Universitas Jambi Seri Humaniora. 13(1): 47-58.

Hanafie R. 2010. Pengantar Ekonomi Pertanian. Yogyakarta (ID): Andi Offset.

Mustofa. 2012. Analisis Ketahanan Pangan Rumah 
Tangga Miskin dan Modal Sosial di Provinsi Daerah Istimewa Yogyakarta. Jurnal Geomedia. 10(1): 29-48.

Rauf A, Rahmawaty, Dewi B, Said TJ. 2013. Sistem Pertanian terpadu di Lahan Pekarangan Mendukung Ketahanan Pangan Berkelanjutan dan Berwawasan Lingkungan. Jurnal Online Pertanian Tropik Pasca Sarjana FP USU. 1(1): 1-8.

Rusyantia A, Dwi H, Eka K. 2010. Kajian Ketahanan Pangan Rumah Tangga Pedesaan dalam Upaya Peningkatan Status Gizi Masyarakat di Kabupaten
Lampung Selatan. Jurnal Penelitian Pertanian Terapan. 10(3): 171-184.

Sumardjo, Firmansyah A, Dharmawan L, Wulandari YP. 2014. Implementasi CSR Program Pengembangan Masyarakat: Inovasi Pemberdayaan Masyarakat PT. Pertamina EP. Subang Field. Bogor (ID): Pusat Kajian Resolusi Konflik Institut Pertanian Bogor.

Syarief R, Sumardjo, Fatchiya A. 2014. Kajian Model Ketahanan Pangan di Wilayah Perbatasan Antar Negara. Jurnal ilmu Pengetahuan Indonesia. 19(1): 9-13. 